University of Nebraska - Lincoln

DigitalCommons@University of Nebraska - Lincoln

Faculty Publications: Department of Teaching, Department of Teaching, Learning and Teacher Learning and Teacher Education

2021

Factors Associated With Novice General Education Teachers' Preparedness to Work With Multilingual Learners: A Multilevel Study

Qizhen Deng Ph.D.

Lydiah Kananu Kiramba

Kara Mitchell Viesca

Follow this and additional works at: https://digitalcommons.unl.edu/teachlearnfacpub

Part of the Curriculum and Instruction Commons, and the Teacher Education and Professional Development Commons

This Article is brought to you for free and open access by the Department of Teaching, Learning and Teacher Education at DigitalCommons@University of Nebraska - Lincoln. It has been accepted for inclusion in Faculty Publications: Department of Teaching, Learning and Teacher Education by an authorized administrator of DigitalCommons@University of Nebraska - Lincoln. 


\title{
Factors Associated With Novice General Education Teachers' Preparedness to Work With Multilingual Learners: A Multilevel Study
}

\author{
Qizhen Deng, ${ }^{1}$ Lydiah Kananu Kiramba, ${ }^{2}$ \\ and Kara Mitchell Viesca² \\ 1 Boise State University, Boise, ID, USA \\ 2 University of Nebraska-Lincoln, Lincoln, NE, USA \\ Corresponding author — Qizhen Deng, Assistant Professor, Department of Literacy, \\ Language and Culture, Boise State University, Education Building 505, 1910 University \\ Drive, Boise, ID 83725-1725, USA. Email: qizhendeng@boisestate.edu \\ ORCID Qizhen Deng https://orcid.org/0000-0003-3323-2433
}

\begin{abstract}
This study examined factors linked to novice general education teachers' perception of their preparedness to work with multilingual learners in the classroom. Using a multilevel modeling approach, we examined factors at the teacher and school levels using two AY 2015 to 2016 datasets: The National Teacher and Principal Survey from the National Center for Education Statistics and the Civil Rights Data Collection from the Office of Civil Rights. The results show that teacher perception of preparedness was positively associated with teacher education courses on working with multilingual learners, supports received during the first-year teaching, and the number of multilingual learners teachers worked within their classrooms. Similarly, the concentration of
\end{abstract}

Published in Journal of Teacher Education (2021), 15pp.

DOI: 10.1177/0022487120971590

Copyright (C) 2020 American Association of Colleges for Teacher Education; published by SAGE Publications. Used by permission. 
multilingual learners at the school level had a positive impact on preparedness. Overall, it appears that experiences both learning about and working with multilingual learners are positively associated with novice general education teachers' perceptions of preparedness to work with multilingual students.

Keywords: Bilingual/English language learners, professional development, school backgrounds, teacher characteristics, teacher education preparation

\section{Introduction}

General education teachers must be well prepared to work with multilingual learners ${ }^{1}$ if they are to provide responsive instruction that builds on the strengths and abilities of all students regardless of their linguistic and cultural backgrounds (Alim et al., 2020; Lucas et al., 2008). Given the increasing population of multilingual learners nationwide, especially across the past two decades (McFarland et al., 2019), most general education teachers are likely to have multilingual students in their classroom at some point in their teaching career. Students at the early stages of developing English proficiency often will work with English as a Second Language (ESL) specialists daily either through pull-out or push-in models, typically for 30 to 60 min (Diaz- Rico, 2020). This means multilingual students, even at the early stages of English development, often spend a great deal of time seeking to learn in general education classrooms. Furthermore, students at later stages of English development continue to benefit from multilingual language- development support in general education teachers' classrooms (Diaz-Rico, 2020). Therefore, if we are to expect teachers to provide quality learning opportunities for the diverse population of multilingual students, it is imperative for all teachers, including general education teachers, to be prepared to support multilingual learners in expanding their knowledge and skills in culturally and linguistically sustaining ways (Alim et al., 2020; Hamann \& Reeves, 2013). However, a growing body of research shows that many general education teachers feel underprepared to work with multilingual learners (e.g., Durgunoğlu \& Hughes, 2010; Faltis \& Valdés, 2016; Hansen-Thomas et al., 2016; O'Neal et al., 2008; Polat, 2010; Reeves, 2006; Rodriguez et al., 2010).

As illustrated above, general education teachers work with multilingual learners at varying stages of English development. The major concern in the research literature and in educational settings surrounds 
multilingual learners at the earlier stages of developing English proficiencies, the subset of multilingual learners we focus on in this study as well. In working with this group of students, general education teachers are responsible to ensure that they simultaneously "attain English proficiency" and "meet academic content and achievement standards" that are expected for all other students (McFarland et al., 2019, p. 56). While these monolithic perspectives of learning and desired outcomes are problematic and do not encompass the full possibilities of engaging in pluralist learning outcomes (Alim et al., 2020), many accountability systems across states hold teachers and students accountable for such learning outcomes and trajectories. The skills, perspectives, theories, and practices necessary to accomplish these goals, while also meaningfully integrating the linguistic and cultural assets students bring to the classroom (e.g., Alim et al., 2020; García et al., 2017), may or may not have been addressed in a teacher's preparation program and/or professional development opportunities. These experiences tend to influence the development of novice teachers' sense of preparedness, which has been shown to be related to teacher practices (Blank et al., 2008; Hansen- Thomas et al., 2016).

To deepen our understandings of novice general education teachers' perceived preparedness to work with multilingual learners, we utilized data from the 2015 to 2016 National Teacher and Principal Survey from the National Center for Education Statistics (NCES) and the 2015 to 2016 Civil Rights Data Collection (CRDC) from the Office of Civil Rights to examine the extent to which novice general education teachers' perceived preparedness to work with multilingual learners in their first year of teaching were linked to factors at the teacherand school-level.

\section{Literature Review}

\section{Teacher Preparedness to Work With Multilingual Learners}

It requires a great deal of expertise for teachers to build on the learning strengths that multilingual learners bring to the classroom while helping students develop strong multilingual proficiencies as well as engage with challenging curriculum (Alim et al., 2020; Civic Impulse, 
2016; García et al., 2017). Overall, teacher-perceived preparedness has been significantly associated with their sense of efficacy, sense of responsibility for student learning, and plans to remain in teaching profession (Darling-Hammond et al., 2002), and effectiveness in general teaching practice (Blank et al., 2008). Research on teacher preparedness to work with multilingual learners illustrates that this perceived preparedness is positively related to teachers' competency in teaching multilingual students. For example, teacher preparedness is associated with teachers' use of effective instructional methods and resources to promote multilingual students' communicative competence and content area learning (Coady et al., 2011; Hansen-Thomas et al., 2016). Furthermore, the perceived preparedness regarding working with multilingual learners among student teachers in general education classrooms is positively linked to their self-efficacy and performance on knowledge tests (Durgunoğlu \& Hughes, 2010).

However, a growing body of literature suggests that the vast majority of general education teachers are underprepared to work effectively with multilingual students (e.g., Durgunoğlu \& Hughes, 2010; Faltis \& Valdés, 2016; Hansen- Thomas et al., 2016; O’Neal et al., 2008; Polat, 2010; Reeves, 2006; Rodriguez et al., 2010). In a sample of rural in-service teachers from 10 districts in Texas, teachers reported having little long-term education on working with multilingual learners. They reported encountering difficulty in communicating with students and their families. Teachers also reported struggling to find ways to help students comprehend spoken and written discourses (Hansen-Thomas et al., 2016). In another study with 19 kindergarten teachers with at least one multilingual student in their classroom, only $5 \%$ of teachers reported having received instruction on multilingual learners through a required course, and $42 \%$ reported having instruction merged throughout several courses (Sullivan et al., 2015). Data with preservice teachers also suggested that they did not feel prepared to work with multilingual students, where no helpful guidance on working with multilingual learners was received during student teaching from their mentor teachers (Durgunoğlu \& Hughes, 2010). In this study, we examined the extent to which a national sample of novice teachers felt prepared to work with multilingual learners. 


\section{Teacher Education Experiences and Teacher Preparedness}

Novice general education teachers' preparedness has been tied to their different experiences in teacher education programs or pathways into teaching. Preservice teachers gain experience working with multilingual students mainly through practicum and field experiences as well as paid employment positions (Sullivan et al., 2015). For example, field experiences involving direct interaction with multilingual learners were perceived by teachers to be most helpful in preparing them to teach multilingual students (e.g., ESL classroom observations, small-group teaching with multilingual students, tutoring multilingual learners through oneon-one format), whereas field experiences without the opportunities to interact with multilingual learners were considered not as helpful (Coady et al., 2011). Several other studies also reported that preservice teachers found field experience where they could interact directly with multilingual students to be most useful in preparing them to work with multilingual learners (e.g., Bollin, 2007; Fitts \& Gross, 2012). It is worth noting, beyond being exposed to multilingual students during field experiences, preservice teachers also need additional guidance from mentor teachers about teaching multilingual learners to be prepared with relevant knowledge and skills. Durgunoğlu and Hughes (2010) reported that preservice teachers without relevant guidance from mentor teachers in working with multilingual students during their student teaching (e.g., integrating language and content instruction, encouraging peer interaction, engaging in pluralistic task and assessment options) ended up gaining little knowledge about teaching multilingual learners and reported themselves to be not well prepared. Daniel (2014) found that teachers candidates gained little knowledge or experience working with mentor teachers when they did not witness mentor teachers meaningfully engaging multilingual learners in their curriculum and instruction. However, these candidates did report learning from working with multilingual learners themselves. Similarly, Mitchell et al. (2012) reported that teacher candidates in a field experience where they engaged in literacyrich read-alouds with multilingual students illustrated positive learning gains. Catalano et al. (2018) also found learning gains, but remained concerned with the "ethnocentrism, gaps in understanding of language practices, continued misconceptions about language learner, and ideologies that view languages other than English as a privilege" (p. 1). Tandon 
et al. (2017) studied 36 teacher candidates' perceptions of linguistic responsiveness by investigating participants' teaching philosophy and reflective essays across the teacher education program, and the findings also suggested that teacher candidates discussed technicist aspects of teaching multilingual students like strategies and scaffolding, but did not expansively discuss language or illustrate an inclination to advocate for multilingual students. They came to a similar conclusion as Catalano et al. (2018) that while teacher candidates appear to be making learning gains, more work is necessary for them to be prepared teachers of multilingual students.

Further research has examined teacher education course practices and structures for their ability to prepare teachers to work with multilingual learners. Jimenez-Silva and Olson (2012) found that professional learning communities within preservice coursework is an effective approach to supporting teachers to learn about working with multilingual students. Using problems of practice also appears to be effective, particularly for teaching pedagogical language knowledge (Galguera, 2011). Walker et al. (2017) examined the affordances and constraints of preparing teachers to work with multilingual students online. Their study found no significant difference between online and on-campus courses in terms of teachers' acquisition of knowledge related to teaching multilingual students. Further studies have evaluated teacher candidates' preparedness due to participation in coursework with a focus on working with multilingual learners (Clark-Goff \& Eslami, 2016; Schall-Leckrone \& McQuillan, 2012; Turgut et al., 2016) and have reported positive impacts on perceptions of preparedness due to course activities and learning objectives (i.e., embedding language-focused strategies in history content method courses, or providing a whole method or assessment course on multilingual students). In this study, we were interested in the role of teacher education experiences (i.e., multilingual-studentrelated courses, methods courses, student teaching duration, highest degree earned, and certification) on teacher-perceived preparedness to work with multilingual students.

\section{First-Year Experiences and Teacher Preparedness}

Novice teachers experience myriad challenges during their first year of teaching, which has been reported to cause teacher attrition (Ingersoll \& 
Strong, 2011; Ronfeldt \& McQueen, 2017). To combat teacher attrition, more than half of the states in the United States require novice teachers to participate in some form of induction or mentoring programs (Goldrick et al., 2012). Different first-year teacher induction methods have been applied toward increasing teacher retention rates such as working with a mentor, ongoing professional development, access to an external network of beginning teachers, standards-based evaluations of beginning teachers as well as the program itself (Ingersoll \& Strong, 2011; Kaufmann, 2007). In a meta-analysis of 15 empirical studies over 25 years, impactful induction programs were reported to reduce novice teachers' frustration rates associated with beginning a teaching career, enhance novice teachers' retention rates, perceptions of preparedness, and classroom instructional practices, as well as positively affect student achievement (Ingersoll \& Strong, 2011). The positive impact of induction programs, however, was dependent on the extent and intensity of the induction teacher received. Ingersoll and Strong (2011) concluded that preservice teacher preparation followed by continued support through induction programs would benefit novice teachers in improving their teaching practices and maintaining higher job satisfaction.

Several empirical studies suggest a positive effect of induction programs on novice teachers' instructional practices (e.g., Allen, 2013; Ronfeldt \& McQueen, 2017; Smith \& Ingersoll, 2004). Teachers who received comprehensive induction with multiple types of support (e.g., mentorship from the same subject field, planning, and collaboration with other teachers), were substantially less likely to leave their schools or the profession after their first year of teaching than those who received less support or no support at all (Smith \& Ingersoll, 2004). Providing novice teachers support around curriculum development was shown to have a positive effect on teacher retention and teachers' skills to produce quality curriculum, but no effect on unaddressed topics such as student assessment (Allen, 2013). In a randomized controlled study with 1,009 novice elementary teachers, comprehensive induction services showed positive impacts on student achievement in reading and math for teachers receiving 2 years of services, but no impacts on teacher attitudes or retention (Glazerman et al., 2010). The induction services focused on mentorship, structured support with professional development opportunities, observations by experienced teachers, and formative assessment tools. Interestingly, the level and intensity of induction services played a 
role, that is, teachers receiving more induction reported higher job satisfaction and preparedness to work with others than those who received less (Glazerman et al., 2010). Building on this body of research, in this study we were interested in the role of several first-year experience variables on teacher-perceived preparedness to work with multilingual students: induction program, teaching support, mentoring frequency and quality, and percentage of multilingual students taught.

\section{School Contexts and Teacher Preparedness}

School context refers to the "hardware" of the school, characterized by "the physical background (e.g., school location and resources), the student body (e.g., school socioeconomic and racial-ethnic compositions), and the teacher body (e.g., levels of teacher education and teaching experience)" (Ma et al., 2008, p. 59). School contexts play a critical role in teaching and learning experiences for students and teachers. For instance, school context variables (e.g., supervisory support, autonomy) were related to emotional exhaustion and reduced personal accomplishment directly, and to job satisfaction indirectly, for teachers at elementary and middle school levels (Skaalvik \& Skaalvik, 2009). School context factors such as school location, level, and size were also reported to relate to teacher job satisfaction (Perie \& Baker, 1997; Shen et al., 2012). Other studies suggested that school-level factors can also affect student outcomes, such as behavioral, emotional, and cognitive engagement in school (Wang \& Eccles, 2013) and the academic achievement of students in middle and high school (Davis \& Jordan, 1994). The literature on the relationship between school-level factors and teacher-perceived preparedness to work with multilingual learners, however, is very limited. Therefore, the nature of the present study was more exploratory in terms of the effect of school context on teacher-perceived preparedness to work with multilingual learners. In this study, we examined the relationship between teacher-perceived preparedness and six schoolcontext variables, including multilingual-learner programs availability, multilingual-learner concentration, socioeconomic status, location, level, and enrollment. 


\section{Theoretical Perspective}

Much of the research literature on working with multilingual students draws from sociocultural theory (e.g., Shaw et al., 2014; Swanson et al., 2014). In fact, some of the most promising research regarding strong pedagogical practices with multilingual learners is grounded in operationalizing sociocultural theory as pedagogy (e.g., Doherty \& Hilberg, 2007; Hilberg et al., 2000; Teemant \& Hausman, 2013). Essentially, sociocultural theory focuses on the contextual nature of learning and how it occurs through interaction, particularly through collaboration and assistance from a more knowledgeable other (Vygotsky, 1980). Therefore, in this study, we underscore the importance of context (Figure 1) in teacher learning and growth. We applied a sociocultural lens to the development of this study (the decision to merge the datasets we merged and analyze the variables we analyzed) and the interpretation of its findings, viewing learning as social and knowledge as cultural. To us, teacher learning and growth simply cannot be disconnected from context.

\section{The Present Study}

This study explored the factors at the teacher-level and school-level that influence public-school general education teachers' perceived preparedness to work with multilingual students in their first year of teaching. The teacher preparation literature suggests that teacher education programs play an essential role in preparing all teachers to work well with multilingual learners (Coady et al., 2011; Tandon et al., 2017). In addition, new teachers' first-year experiences can also impact their sense of preparedness (Danielson, 1999; Glazerman et al., 2010; Ingersoll \& Strong, 2011). Last but not least, school-level factors can potentially play a role in teacher-perceived preparedness. A conceptual framework (see Figure 1) illustrates our effort to examine the potential factors affecting teacher-perceived preparedness to work with multilingual learners. Based on the literature, theoretical perspective, and conceptual framework, we asked the following research questions about general education teachers: 


\section{Teacher Education Experiences}

1. Multilingual-Learner Related Courses

2. Number of Methods Courses

3. Classroom Numbers for Student Teaching

4. Length for Student Teaching

5. Highest Degree

6. Teaching Certification

\section{First-Year Experience}

1. Induction Program

2. Teaching Support

3. Mentoring Frequency

4. Mentoring Quality

5. \% of Multilingual Learners Taught

\section{School Contexts}

1. Multilingual-Learner Program Availability

2. Multilingual-Learner Concentration

3. Socioeconomic Status

4. School Location

5. School Grade Level

6. Total Student Enrollment
Teacher Demographics

1. Gender

2. Age

3. Race

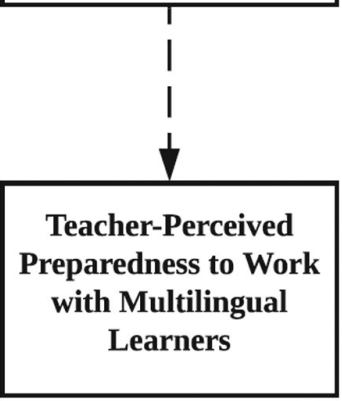

Teacher-Perceived with Multilingual Learners

Figure 1. The conceptual framework.

1. To what extent did teachers report feeling prepared to work with multilingual learners in their first year of teaching?

2. To what extent were teacher-perceived preparedness to work with multilingual learners related to their preservice teacher education experiences?

3. To what extent were teacher-perceived preparedness to work with multilingual learners related to their first-year teaching experiences?

4. To what extent were teacher-perceived preparedness to work with multilingual learners related to school contexts where they taught? 


\section{Methods}

\section{Data Source and Samples}

In this study, we linked two nationally representative datasets to include the information at two analysis levels: teacher and school. One was the latest available public-school data from the 2015 to 2016 National Teachers and Principal Survey (NTPS) from the NCES, which comprised the majority of the data for this study. NTPS is a large sample survey that aims to collect information about public elementary and secondary schools and their staff in the United States. NTPS was designed by NCES of the U.S. Department of Education and implemented by the U.S. Census Bureau. First administered in the 2015 to 2016 school year, NTPS will collect data every 2 years on the topics of teacher and principal preparation, demographics of teachers and principal workforce, school characteristics, and classes taught, and every 4 years on additional educational topics such as professional development and working conditions. Data collection used a combined mail-based and internet survey approach with subsequent telephone and in-person field follow-up. For sample selection, NTPS selected schools using a probability-proportionate-to-size algorithm without stratifying schools before sampling. NTPS is confined to the 50 states plus the District of Columbia excluding territories and overseas schools, where the selection began with schools and teachers were subsampled within sampled schools. The weighted unit response rates for the 2015 to 2016 school year were $68 \%$ for teachers and $73 \%$ for schools.

For this study, we used data from the Teacher Questionnaire and School Questionnaire. The purpose of the Teacher Questionnaire was to collect teacher information such as general background, education information, early career experiences, working conditions, school climate, and teacher attitudes. The School Questionnaire was to obtain information of school characteristics, such as demographics, staffing, and programs. For this study, all sampled teachers who responded to the teacher preparedness question (dependent variable) in the Teacher Questionnaire were included.

We also used the CRDC to extract school-level information in the 2015 to 2016 school year in terms of the enrollment of students labeled as "English Learner." CRDC was a survey of all public schools and school 
districts in the United States that collects information about school characteristics, programs, services, and student outcomes. As a result of combining these two datasets, our sample included a total of 6,670 teachers and 3,770 schools, representing a weighted sample of 754,100 teachers and 86,980 schools. All numbers in this study were rounded to the nearest 10 per NCES clearance requirements.

\section{Variables and Measures}

Most variables in this study were item-level results directly extracted from the 2015 to 2016 NTPS. Some items were ready-for-use composites in the NTPS database created by NCES using the data collected. The details and descriptive statistics of all variables in this study are presented in the Appendix.

Teacher preparedness. Teacher-perceived preparedness to work with multilingual learners was measured by one four-point item where teachers were asked to respond to "In your FIRST year of teaching, how well prepared were you to teach students who are limited-English proficient [LEP] or English-language learners [ELLs]?"

Teacher-level variables. We extracted 14 variables at the teacher level, including three items on teachers' general background information (e.g., Gender, Race), six items on education information (e.g., Methods, Certification), and five items on first-year teaching experience (e.g., Induction, Teacher Support) (see the Appendix for details).

School-level variables. There were six school-level variables (e.g., Concentration of Multilingual Students, Location, Level, and Size) (see the Appendix for details). Concentration of Multilingual Learners was resulted from grouping the percentage of multilingual Learners into four categories ( $1=0 \% ; 2=>0 \%$ to $<5 \%, 3=5 \%$ to $<20 \% ; 4=>20 \%$ ) using the grouping schema applied by the U.S. Department of Education (2017).

Linking variables. We used the linking variable (school control number) to combine the data from the teacher and school questionnaires of the NTPS. Once combined, we added the multilingual learner enrollment information from the CRDC to calculate the concentration of multilingual 
learners at the school level. The linking variable from the CRDC was COMBOKEY (i.e., the combination of seven-digit district ID plus the fivedigit school ID) that match the unique school ID assigned to each school by NCES.

\section{Statistical Analysis}

We applied multilevel modeling considering the hierarchical nature of educational data using the software Mplus (version 7). Teachers' responses are nested within schools as teacher responses within the same school might be affected by common school contexts (Ingersoll \& Strong, 2011). Therefore, we conducted multilevel modeling for the dependent variable of teacher-perceived preparedness ( $t$ prep). We developed four models to answer our research questions: (a) the unconditional model, (b) the controlling model with three controlling variables, (c) the teacher-level model with additional 11 teacher-level variables, and (d) the school-level model with six school-level variables. Each model was built on the previous one.

The unconditional model without any predictors was:

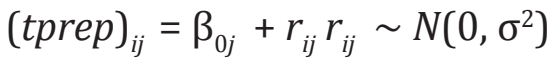

$$
\begin{aligned}
& \beta_{0 j}=\gamma_{o o}+\mu_{o j} \mu_{o j} \sim N\left(0, \tau_{00}\right)
\end{aligned}
$$

Where $(\text { tprep })_{i j}$ was the teacher-perceived preparedness for teacher $i$ in school $j, \beta_{0 j}$ was the mean score in school $j, r_{i j}$ is the teacher-level random effect (regression slope), and $\sigma^{2}$ was the variability within schools. $\gamma_{o o}$ was the grand mean, $\mu_{o j}$ was the school-level random effect, and $\tau_{00}$ was the variability across schools.

In the second model, three teacher-level controlling variables were added:

$$
\begin{aligned}
& (\text { tprep })_{i j}=\beta_{0 j}+\beta_{1 j}(\text { Gender })+\beta_{2 j}(\text { Age })+\beta_{3 j}(\text { Race })+r_{i j} \\
& \beta_{0 j}=\gamma_{o o}+\mu_{0 j} \\
& \ldots \\
& \beta_{3 j}=\gamma_{3 o}+\mu_{3 j}
\end{aligned}
$$

where $\beta_{0 j}-\beta_{3 j}$ were the effects of the teacher-level controlling variables, and $\gamma_{o o}$ was the grand mean, $\mu_{0 j}$ was the school-level random effect. In this model, all variables were group-mean centered (Peugh, 2010). 
In the third model, 11 teacher-level variables were added:

$$
\begin{aligned}
& (\text { tprep })_{i j}=\beta_{0 j}+\beta_{1 j}(\text { Gender })+\beta_{2 j}(\text { Age }) \\
& +\beta_{3 j}(\text { Race })++\beta_{4 j}\left(M L L_{\text {course }}\right)+\beta_{5 j}(\text { Methods }) \\
& +\beta_{6 j}(\text { StudentTeach } \text { classrooms }) \\
& +\beta_{7 j}(\text { StudentTeach } \text { duration }) \\
& +\beta_{8 j}(\text { HighestDegree })+\beta_{9 j}(\text { Certificate }) \\
& +\beta_{10 j} \text { (Induction) }+\beta_{11 j} \text { (TeacherSupport) } \\
& +\beta_{12 j}\left(\text { Mentor }_{\text {freq }}\right)+\beta_{13 j}\left(\text { Mentor }_{\text {qual }}\right) \\
& +\beta_{14 j}(M L L \%)+r_{i j} \\
& \beta_{0 j}=\gamma_{o o}+\mu_{o j} \\
& \text {... } \\
& \beta_{14 j}=\gamma_{140}+\mu_{14 j}
\end{aligned}
$$

where $\beta_{0 j}-\beta_{14 j}$ were the random effects of the teacher-level variables, and $\gamma_{o o}$ was the grand mean, $\mu_{o j}$ was the school-level random effect. All variables were group-mean centered (Peugh, 2010).

In model four, six school-level variables were added:

$$
\begin{aligned}
& \text { (tprep })_{i j}=\beta_{0 j}+\beta_{1 j}(\text { Gender })+\beta_{2 j}(\text { Age }) \\
& +\beta_{3 j}(\text { Race })++\beta_{4 j}\left(M L L_{\text {course }}\right)+\beta_{5 j}(\text { Methods }) \\
& +\beta_{6 j}(\text { StudentTeach } \text { classrooms } \text { ) } \\
& +\beta_{7 j}\left(\text { StudentTeach }{ }_{\text {duration }}\right)+\beta_{8 j}(\text { HighestDegree }) \\
& \left.+\beta_{9 j} \text { (Certificate }\right)+\beta_{10 j} \text { (Induction) } \\
& +\beta_{11 j}(\text { TeacherSupport })+\beta_{12 j}\left(\text { Mentor }_{\text {freq }}\right) \\
& +\beta_{13 j}\left(\text { Mentor }_{\text {qual }}\right)+\beta_{14 j}(M L L \%)+r_{i j} \\
& \beta_{0 j}=\gamma_{o o}+\gamma_{o 1}(\text { MLLinstr })+\gamma_{o 2}(\text { MLLconcentr }) \\
& +\gamma_{o 3}(\text { SES })+\gamma_{o 4}(\text { Location })+\gamma_{o 5}(\text { Level }) \\
& +\gamma_{o 6}(\text { Size })+\mu_{0 j} \\
& \beta_{1 j}=\gamma_{10}+\mu_{1 j} \\
& \text {... } \\
& \beta_{14 j}=\gamma_{14 o}+\mu_{14 j}
\end{aligned}
$$

where $\gamma_{o o}-\gamma_{o 6}$ were the school level fixed effects and $\mu_{o j}-\mu_{14 j}$ are the random effects of the teacher-level slopes. Other parameters are the same as in the previous model. All-school-level predictors were grand-mean centered (Peugh, 2010). 


\section{Results}

This study examined the perceived preparedness of public-school general education teachers to work with multilingual learners in their first year of teaching as well as teacher-level and school-level factors that might affect their perceived preparedness. Tables 1 and 2 present the teacher- and school-level correlations that were all significant due to the large sample size. However, the low correlations indicated no multicollinearity problem. Descriptive statistics for all variables are available in the Appendix. Table 3 presents the multilevel analysis results.

Overall, the results revealed that the average score of teacher-perceived preparedness was 2.16 on a four-point scale, suggesting teachers were at the lower end of feeling prepared to work with multilingual learners. The results also suggested that the variance of teacher-perceived preparedness were composed of teacher-level (.690) and schoollevel variance (.073). Therefore, the intra-class correlation (ICC) is .097, which is considered to be "reasonable" in educational contexts (Hox et al., 2017). The ICC value suggested that $9.7 \%$ of the variance of teacherperceived preparedness can be explained by school-level factors, which justified the procedure to explore the impact of average scores of schoollevel factors.

\section{Controlling Variables and Teacher Preparedness}

The results of the controlling model (Model 2 Table 3) suggest that teacher-perceived preparedness was significantly associated with gender but not with age $(\gamma=.002, p=.357)$ and race $(\gamma=.08, p=.075)$. Female teachers $(M=2.21, S D=0.88)$ reported significantly higher preparedness than male teachers $(M=2.10, S D=0.86)(\gamma=.01, p=.007)$. This model explained $8.3 \%$ of the variance and the residual variance was $67.3 \%(p<.001)$.

\section{Teacher Education Experiences and Teacher Preparedness}

This model explained $22 \%$ of the original within-level variance at the teacher-level (Model 3 Table 3) with the residual within-level variance being .54 ( $p<.001)$. For teacher education experiences, only one out of the six variables significantly affected teacher-perceived preparedness 


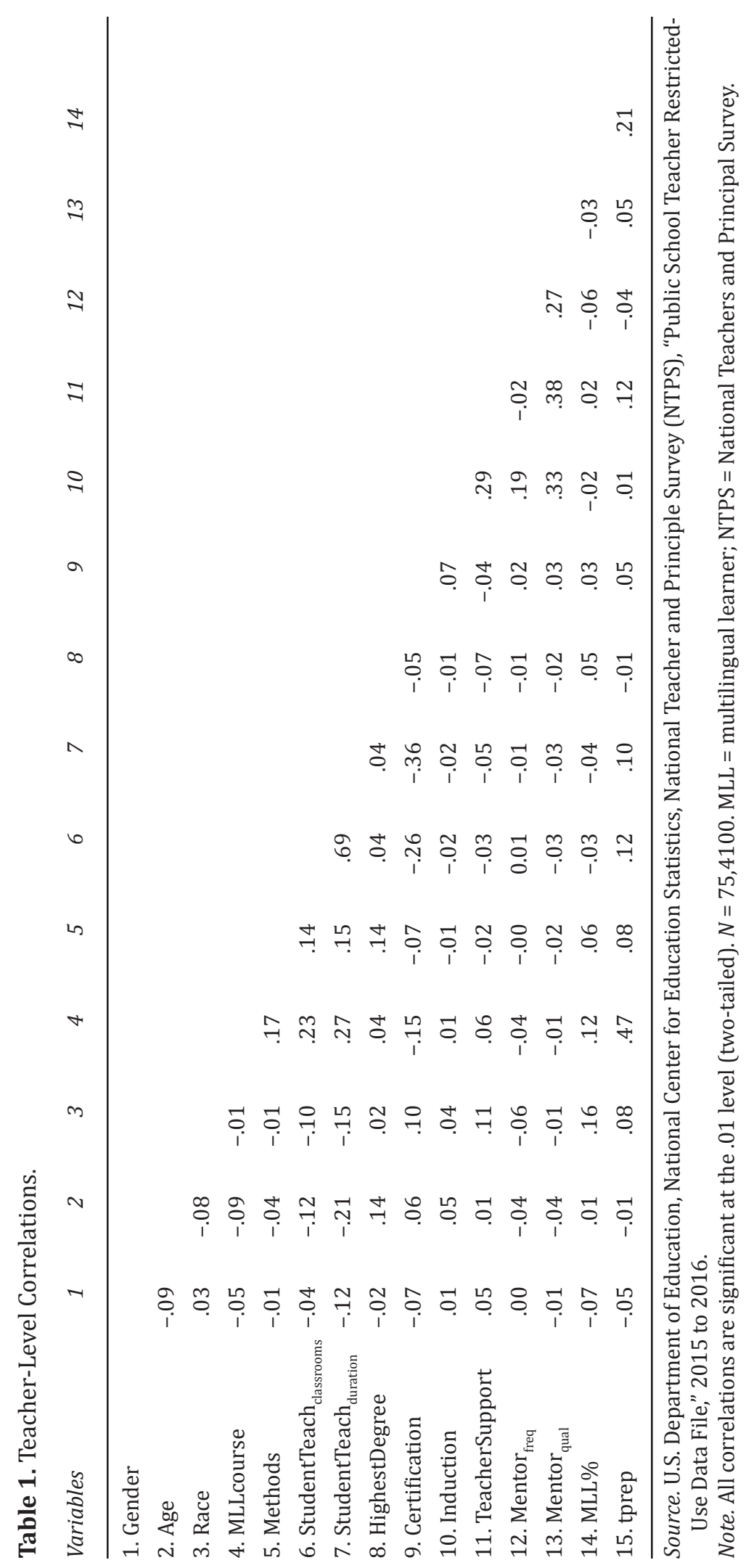


Table 2. School-Level Correlations.

\begin{tabular}{|c|c|c|c|c|c|c|}
\hline Variables & 1 & $2^{a}$ & 3 & 4 & 5 & 6 \\
\hline \multicolumn{7}{|l|}{ 1. ELLinstr } \\
\hline 2. ELLconcentra & .46 & & & & & \\
\hline 3. Socioeconomic Status & .03 & .22 & & & & \\
\hline 4. Location & .20 & .33 & -.01 & & & \\
\hline 5. Level & .08 & .24 & .07 & -.10 & & \\
\hline 6. Size & .21 & .11 & -.20 & -.24 & .16 & \\
\hline 7. tprep & .11 & .19 & -.01 & -.09 & -.09 & .02 \\
\hline
\end{tabular}

Source. U.S. Department of Education, National Center for Education Statistics, National Teacher and Principle Survey (NTPS), "Public School Restricted-Use Data File," 2015 to 2016.

Note. $N=86,980$ except for ELLconcentr $\left({ }^{a} n=83,530\right)$. ELL= Englishlanguage learners; NTPS = National Teachers and Principal Survey.

to work with multilingual students, that is, whether they had taken a course(s) on teaching multilingual students. Specifically, teachers who had taken any such graduate or undergraduate courses $(M=2.55, S D=$ $0.79)$ reported being significantly more prepared to work with multilingual learners than those who did not take any $(M=1.73, S D=0.75)(\gamma=$ $.69, p<.001)$, with the proportional reduction in variance being $16.8 \%$ (a medium effect size) (Cohen, 1992; Peugh, 2010). The rest of the factors (i.e., Number of Method Courses, Number of Classrooms Student Taught, Student Teaching Duration, Highest Degree, Certification) were not associated with teacher-perceived preparedness to work with multilingual learners.

\section{First-Year Experiences and Teacher Preparedness}

The results (Model 3 Table 3) suggest that teacher-perceived preparedness to work with multilingual learners was significantly linked to the total number of kinds of teacher support they received during the first year of teaching $(\gamma=.05, p<.001)$ with the variance reduction being $4.2 \%$ (a small effect size), but not linked to the frequency and quality of mentoring. In addition, the availability of induction programs was close to being significantly related to teacher-perceived preparedness to work with multilingual students $(\gamma=.07, p=.069)$. Last, the percentage of teachers' students who were multilingual learners had a significant positive effect on their perceived preparedness $(\gamma=.01, p<.001)$ 


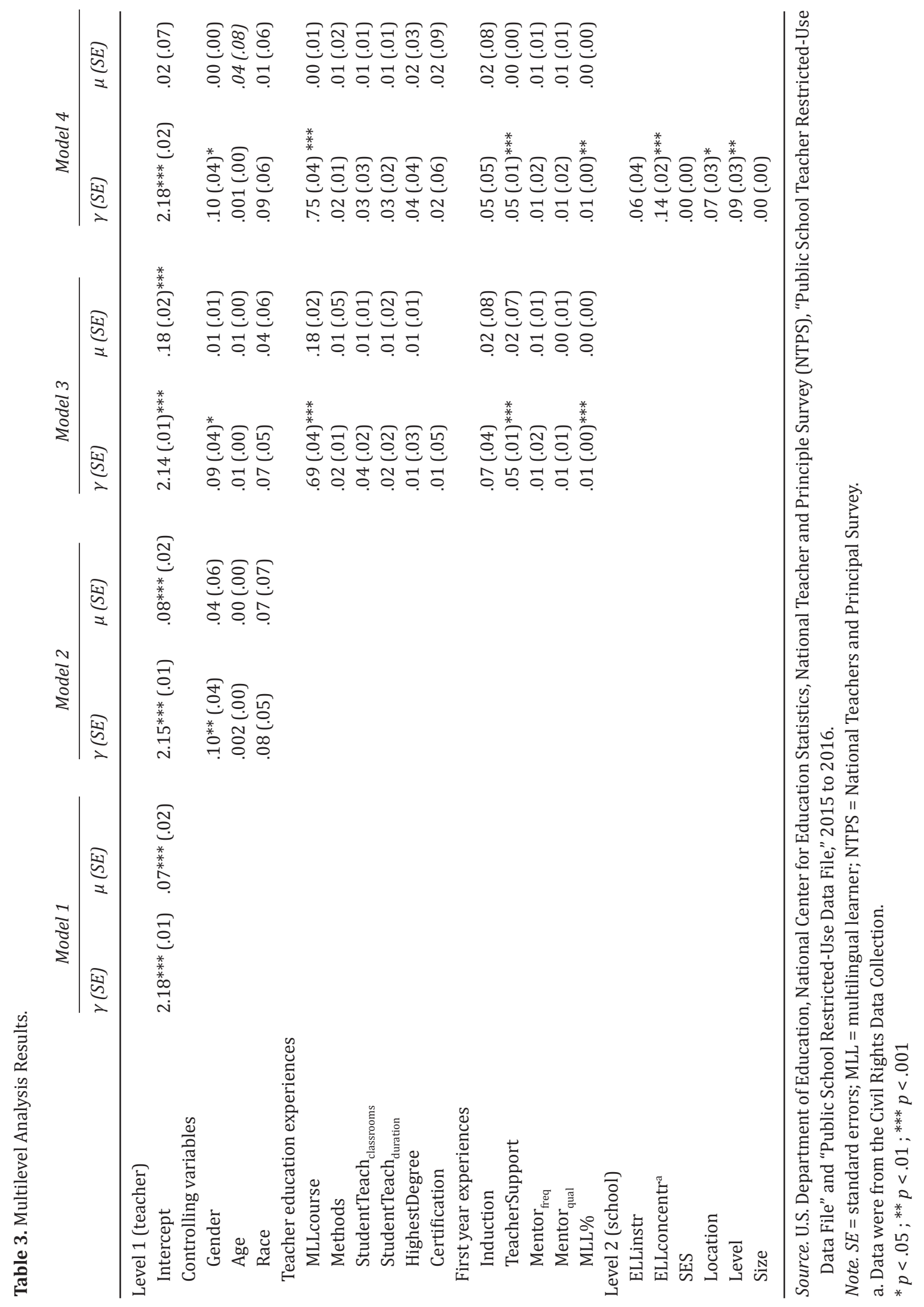


with the variance reduction being 6.4\% (a small effect size). This suggests that the higher percentage of multilingual students in their classrooms led to teachers' feeling more prepared to teach them. No additional significant relationship was found.

\section{School Contexts and Teacher Preparedness}

Model 4 in Table 3 presents the results of school-level effects on teacherperceived preparedness. Three out of the six school-level factors had significant effects on teacher-perceived preparedness. Specifically, the concentration of multilingual learners was significantly linked to teacher-perceived preparedness, indicating that the higher percentage of multilingual learners in the school, the more likely the teachers were to report feeling prepared to teach them $(\gamma=.128, p<.001)$ with the proportional reduction in variance being 2.4\% (a small effect size). For school location, teachers in suburban/city areas $(M=2.24, S D=0.88)$ reported higher preparedness than teachers in towns/rural areas $(M=$ $2.07, S D=0.86)(\gamma=.064, p=.043)$, with the proportional reduction in variance being 5.2\% (a small effect size). As for school level, elementary teachers $(M=2.26, S D=0.88)$ reported higher perceived preparedness than secondary teachers $(M=2.09, S D=0.86)(\gamma=.085, p=.010)$ with the variance reduction being $2.0 \%$ (a small effect size). However, the availability of multilingual learner-related instruction, socioeconomic status, and size did not affect teachers' reported preparedness.

In this model, the variance explained at the teacher-level was $32 \%$ of the original within-level variance. The residual within-level variance was .469 $(p<.001)$ and the residual school-level variance was reduced to .030 and was no longer significant. This suggested that the inclusion of school-level factors explained most of the between-level variance (80\%) in the previous model (Model 3).

\section{Discussion}

The results of this study suggest that, overall, public school general education teachers reported not being well prepared to work with multilingual learners, similar to previous reports on teacher-perceived being inadequately prepared to teach multilingual students (e.g., Hansen-Thomas 
et al., 2016; O’Neal et al., 2008; Polat, 2010; Reeves, 2006; Rodriguez et al., 2010). However, we also found some variables that appear to positively impact teacher-perceived preparedness that are worth noting and information ongoing teacher education practice and research.

\section{Teacher Education Experiences and Teacher Preparedness}

In terms of teachers' education background, only one variable was significantly associated with teacher-perceived preparedness to work with multilingual learners, that is, whether teachers had taken any graduate or undergraduate courses focusing on teaching multilingual learners. Our result is congruent with previous research on teacher education in relation to multilingual learners and their preparedness to teach multilingual students in the classroom (Hansen-Thomas et al., 2016; López \& McEneaney, 2012). For example, Hansen-Thomas et al. (2016) reported that teacher-perceived their competency in working with multilingual learners (e.g., instructional methods, promoting MLLs' communicative competence in English) was highly positively related to their prior education background in terms of whether they had taken one or more college courses on teaching multilingual students, and highly negatively linked to no coursework on teaching multilingual students. Our results suggest that it is critical to offer quality education opportunities via coursework focused on multilingual students for preservice teachers. Providing multilingual student-related preservice learning opportunities also has shown positive effects on teachers' sense of self-efficacy and their acceptance of home language usage among multilingual students (Clark-Goff \& Eslami, 2016).

Teacher-perceived preparedness to work with multilingual learners was not associated with the number of methods courses taken, the number of classroom teachers engaged in for student teaching, the duration of student teaching, highest degree earned, and the type of teaching certification. This might be because these factors do not necessarily guarantee learning opportunities directly tied to working with multilingual students.

\section{First-Year Experiences and Teacher Preparedness}

Our findings suggest that participation in teacher induction programs was not significantly associated with teacher-perceived preparedness 
to work with multilingual learners. However, further investigation indicated the number of kinds of specific support teachers received (i.e., reduced teaching schedule or number of preparations, common planning time with teachers, seminars for beginning teachers, extra classroom assistance, regular supportive communication with the principal or other administrators, observation and feedback on your teaching beyond any formal administrative observation and feedback, and release time to participate in support activities) was statistically significantly associated with teacher-perceived preparedness. This suggests that teachers simply participating in induction programs did not contribute to preparedness, but the variability and quality of first-year supports played an important role in supporting novice teachers in working effectively with multilingual learners. Our finding is congruent with the existing literature showing first-year quality support for novice teachers is crucial in their instructional performance and in developing their beliefs and practices that allow them to navigate the challenges of first-year teaching (Allen, 2013). We also consider several of the specific supports in this study as consistent with the research literature that value teachers collaborating and learning in collaboration, particularly to improve their work with multilingual learners (e.g., Babinski et al., 2018; Martin-Beltran \& Peercy, 2014; Peercy et al., 2015). Based on the existing literature, our theoretical perspective, and our findings, it appears that supporting first-year teachers through meaningful collaborative experiences can impact their perceptions of preparedness to work with multilingual students. Furthermore, we theorize that having teachers simply participate in an induction program does not guarantee preparedness. Rather, the intertwined and substantial teacher supports (the total kinds of support available to new teachers) do matter.

In addition, the frequency of meeting with mentors and perceived quality of mentorship (whether mentorship improved first-year teaching) did not predict teacher-perceived preparedness to work with multilingual students. While this finding is to some extent surprising, it could also be because of the reality that mentors may not have a specialized background or expertise in working with multilingual students. We cannot assume that any mentor available to a general education teacher might have that expertise or background themselves, so it does not appear to currently be a strong factor in impacting perceived preparedness to work with multilingual students among novice teachers. 


\section{School Contexts and Teacher Preparedness}

The results suggested that novice general education teacher-perceived preparedness to work with multilingual learners was significantly and positively linked to the concentration of multilingual students at the school where teachers worked, that is, the higher the percentage of multilingual students, the more prepared teachers reported to be. This relates to findings from Master et al. (2016) who analyzed New York City School data regarding both teachers and student outcomes and found that the impact of teachers' experience working with multilingual students was positive from one year to the next on student achievement. Other research has documented the benefit for teacher learning and effective practice with multilingual students linked to experiences working with multilingual learners both in preservice and in-service (Daniel, 2014; Fitts \& Gross, 2012; Mitchell et al., 2012; Sowa, 2009). While our finding is related to the concentration of multilingual students at the school level, in relation to existing research, we theorize that our finding stems from the opportunity for teachers to work with multilingual students impacting their perceived preparedness. We also theorize that schools with higher concentrations of multilingual learners may also have more targeted resources to support both students and teachers. However, in the context of growing segregation, particularly for Latinx students across the United States (Frankenberg et al., 2019), we urge caution in the use and interpretation of this finding. We know that segregating multilingual students has long been a problematic practice in K-12 settings (e.g., Nieto, 2000; Valdés, 2001) and do not encourage that practice to continue or expand due to the results of this study. Rather, we suggest, those supporting teacher development consider and design opportunities for teachers to work extensively with multilingual populations as such work appears to significantly positively impact reported perceptions of preparedness by novice teachers working with multilingual students.

The location of schools played a role in teacher-perceived preparedness. Teachers in suburbs or city areas felt more prepared to teach multilingual students than their counterparts in towns and rural areas. This result is congruent with previous work suggesting a lack of teacher preparedness to work with multilingual students in rural areas. HansenThomas et al. (2016) reported that rural teachers were challenged to 
communicate with multilingual learners and their parents, and the authors concluded with a call to better prepare rural teachers to work with multilingual students through appropriately crafted and accessible professional development (e.g., college-level courses on multilingual students). Wenger et al. (2012) reported that in addition to unpreparedness, rural education is also featured by a primarily White teacher workforce that is resistant to adapting non-Euro-centric pedagogy and curriculum to serve diverse populations (Han \& Leonard, 2017). To some degree, our finding might be systemic and cyclical in nature given that teacher preparation programs in more rural areas tend to have less access to multilingual populations than in city/urban areas, may require less coursework on multilingual populations, and may have teacher candidates with less diverse K-12 educational experiences (i.e., as K-12 students themselves) who tend to return to environments similar to their schooling. In rural contexts in 2016, multilingual students constituted $6.5 \%$ of students in towns and $3.8 \%$ in rural areas compared to $23.3 \%$ in city/ suburban areas, with a higher percentage in lower grades than in upper grades (McFarland et al., 2019). Most of these students are concentrated in a small number of regional schools with higher than average rates of poverty and lower than average rates of academic performance (Barley \& Wegner, 2010; Showalter et al., 2017) as well as resource challenges (Vaughn \& Saul, 2013). We believe there is the need to offer more appropriate and tangible professional development opportunities targeting rural teachers working with multilingual students, such as awareness of the diversity in town and rural areas and the specific perspectives and pedagogies to support quality teaching and learning for multilingual students in those areas (Alim et al., 2020; AnthonyStevens \& Langford, 2020; García et al., 2017). This is especially critical for rural teachers with less exposure to diversity in their own educational and teacher preparation experiences but who have multilingual students in their classrooms.

Interestingly, our analysis revealed that teacher preparedness was not related to the availability of ESL instruction at the school. This might be because there are a large variety of ESL programs across the country, and implementation of the variety of program options are up to the discretion of individual districts and schools. As a result, these programs vary in terms of guiding philosophical frameworks and policy and procedures (e.g., pull-out and push-in program). This freedom, however, does present questions in terms of consistency in implementation across 
ESL programs (Huseby, 2018; López \& McEneaney, 2012) and, consequently, lead to varied results in terms of their effectiveness in teaching and student learning.

Teacher-perceived preparedness to work with multilingual students was not related to the socioeconomic status of the school and the size of the school. Although we were not able to identify relevant studies that examined the association between teacher-perceived preparedness and school size, we theorize that this finding illustrates the complexities and possibilities of working well with multilingual learners in schools of all sizes. Due to the incredible diversity of the multilingual student population and the expansive diversity across schools of varying sizes, that there was no consistent finding regarding school size and teacher-perceived preparedness appears to underscore the complexities of such diversity. Teacher-perceived preparedness was also not associated with the socioeconomic status of school. This is promising as teachers, regardless of the socioeconomic status of school, did not differ in terms of their perceptions of preparedness to work with multilingual students.

\section{Conclusion and Future Directions}

These results have implications for improving teacher quality and subsequently enhancing the learning opportunities for multilingual students. In combination, our findings suggest the need for concentrated and explicit coursework in preservice teacher preparation programs that specifically supports teachers in learning about working with multilingual learners (e.g., Alim et al., 2020; García et al., 2017). Overall, teachers in this study did not feel well prepared to work with multilingual students, but higher levels of perceived preparedness was with teachers who did have such courses. We suggest that such coursework needs to be part of every teacher-preparation program and likely expanded to support higher levels of perceived preparedness with general education teachers.

Our findings also suggest the need for supportive new teacher induction programs built around teacher collaboration and opportunities for pre- and in-service teachers to work extensively with multilingual students. Separately and in combination, these variables have a strong impact on new teachers' perceived preparedness to work with multilingual students. 
Based on these findings, we call for continued research to understand factors that impact teacher-perceived preparedness to teach multilingual learners as well as the relationship between teacher preparedness and other desirable outcomes for both teachers and students (e.g., pluralist learning outcomes, cultural and linguistic connections to communities, graduation rates, teacher retention and satisfaction). Due to our finding that coursework focused on preparing preservice teachers of multilingual learners impacts new teachers-perceived preparedness, further research into the principles, processes, and practices in preservice coursework working with multilingual students is beneficial. Currently, there is coursework-based research looking at various activities and approaches (e.g., Andrews \& Weisenberg, 2013). However, what we are arguing for here is beyond a focus on activities and approaches-rather the kinds of principles and theories that should guide and inform the design and implementation of strong coursework to support the development of quality general education teachers of multilingual learners. The Enduring Principles of Learning (also known as the Standards for Effective Pedagogy) are a strong empirically and theoretically grounded example of this kind of work (e.g., Teemant \& Hausman, 2013; Viesca \& Teemant, 2019): joint productive activity, language and literacy development, contextualization, teaching complex thinking, instructional conversation and critical stance. We also see opportunities for preservice programs to work more collaboratively across institutions to develop principle-based courses that can then be part of larger collaborative research projects.

Because of our finding that supportive teacher induction practices, particularly grounded in collaboration, impact teachers-perceived preparedness to work with multilingual students, we suggest further development and research of strong collaboratively based induction practices that particularly focus on developing strong teachers of multilingual learners. The research literature suggests inter-disciplinary collaborations that include both language specialists and general education teachers are particularly helpful (Babinski et al., 2018; Martin-Beltran \& Peercy, 2014; Peercy et al., 2015). Finally, it is clearly important for teachers to have the opportunities to learn about and work directly with multilingual students. Multilingual students themselves are great teachers of how to be a great teacher of multilingual learners. While we would not suggest that students have the burden to teach teachers to be 
successful teachers of multilingual students, we do argue that there is a valuable learning opportunity in mediated and supported opportunities for teachers to work with multilingual students. These opportunities should ideally be available to both pre- and in-service teachers and are fruitful grounds for further research into the nuance, opportunities and pitfalls of such work.

Acknowledgments We thank the reviewers and Guy Trainin for their insights in improving this manuscript.

Conflicting Interests The authors declared no potential conflicts of interest with respect to the research, authorship, and publication of this article.

Funding The authors received no financial support for the research, authorship, and publication of this article.

\section{Note}

1. We used the term multilingual learners to refer to a population of students who live a multilingual daily reality. For some students, their multilingual daily reality includes a label from the school and/or district of being an "English learner" due to a real or perceived English deficiency; for other students, they have never received this label or have been exited out of programs focused on supporting their English development (Catalano et al., 2020). We feel it is important to attend to all students in their whole complexity across levels of English proficiency and their entire educational lifespan.

\section{References}

Alim, H. S., Paris, D., \& Wong, C. P. (2020). Culturally sustaining pedagogy: A critical framework for centering communities. In N. S. Nasir, C. D. Lee, R. Pea, \& M. M. de Royston (Eds.), Handbook of the cultural foundations of learning (pp. 261-276). Routledge.

Allen, L. V. Z. (2013). The impact of induction support on teacher development, teacher retention, and the teacher quality issue. Teacher Education Quarterly, 40(3), 75-92.

Andrews, D., \& Weisenberg, A. W. (2013). Teaching credential candidates how to adapt lessons and increase vocabulary for English learners. NABE Journal of Research and Practice, 4(1), 1-15. 
Appendix. Descriptive Statistics for all Variables.

\begin{tabular}{|c|c|c|c|c|}
\hline Variables & $\begin{array}{l}\text { Name and representation in } \\
\text { the NTPS and CRDC }\end{array}$ & Coding & $\begin{array}{l}\text { Weighted } \\
\text { sample }\end{array}$ & Statistics \\
\hline \multirow[t]{2}{*}{ Tprep } & Teacher-perceived preparedness & 1 = not at all prepared; & 754,100 & $M=2.19$ \\
\hline & $\begin{array}{l}\text { to work with multilingual } \\
\text { learners (T1513) }\end{array}$ & $\begin{array}{l}2=\text { somewhat prepared; } \\
3 \text { = well prepared; } \\
4 \text { = very well prepared }\end{array}$ & & $S D=0.87$ \\
\hline \multicolumn{5}{|l|}{ Teacher level } \\
\hline Gender & Gender (T0924) & $\begin{array}{l}0=\text { Female } \\
1=\text { Male }\end{array}$ & 754,100 & $\begin{array}{l}24 \% \\
76 \%\end{array}$ \\
\hline Age & Age (AGE_T, generated by NCES) & Continuous & 754,100 & $\begin{array}{l}M=31.02 \\
S D=8.40\end{array}$ \\
\hline Race & $\begin{array}{l}\text { Race (T0928, T0929, T0930, } \\
\text { T0931, т0932, т0933) }\end{array}$ & $\begin{array}{l}0=\text { Others } \\
1=\text { non-Hispanic White }\end{array}$ & 754,100 & $\begin{array}{l}24 \% \\
76 \%\end{array}$ \\
\hline \multirow[t]{2}{*}{ MLLcourse ${ }^{\mathrm{a}}$} & Whether taken graduate or & $0=$ no & 754,100 & $44 \%$ \\
\hline & $\begin{array}{l}\text { undergraduate courses on } \\
\text { teaching multilingual } \\
\text { learners? (T0346) }\end{array}$ & $1=$ yes & & $56 \%$ \\
\hline Methods & $\begin{array}{l}\text { Number of method courses } \\
\text { (T0338) }\end{array}$ & $\begin{array}{l}\text { Continuous }(0=0 ; 1=1 \text { or } 2 \\
2=3 \text { or } 4 ; 3=5 \text { to } 9 \\
4=10 \text { or more })\end{array}$ & 754,100 & $\begin{array}{l}M=1.89 \\
S D=1.42\end{array}$ \\
\hline StudentTeach $_{\text {classrooms }}$ & $\begin{array}{l}\text { Number of classrooms for } \\
\text { student teaching (T0347, T0348) }\end{array}$ & $\begin{array}{l}\text { Continuous }(0=0 ; 1=1 ; \\
2=2 ; 3=3 \text { or more })\end{array}$ & 754,100 & $\begin{array}{l}M=1.59 \\
S D=1.02\end{array}$ \\
\hline StudentTeach $_{\text {duration }}$ & $\begin{array}{l}\text { Length for student teaching } \\
\text { (T0347, T0349) }\end{array}$ & $\begin{array}{l}\text { Continuous }(0=\text { none; } \\
1=4 \text { weeks or less; } \\
2=5-7 \text { weeks; } 3=8-11 \text { weeks; } \\
4=12 \text { weeks or more })\end{array}$ & 754,100 & $\begin{array}{l}M=3.02 \\
S D=1.52\end{array}$ \\
\hline Degree & $\begin{array}{l}\text { Highest degree (HIDEGR, } \\
\text { created by NCES) }\end{array}$ & $\begin{array}{l}1 \text { = associate's or no college degree; } \\
2 \text { = bachelor's; } \\
3 \text { = master's; } \\
4 \text { = Education specialist or certificate } \\
\text { of advanced graduate studies; } \\
5 \text { = doctoral or professional degree }\end{array}$ & 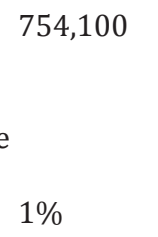 & $\begin{array}{l}3 \% \\
65 \% \\
28 \% \\
3 \%\end{array}$ \\
\hline Certificate & Certification (T0401) & $\begin{array}{l}0=\text { None } / \text { emergency } / \text { provisional; } \\
1 \text { = Probationary } / \text { standard }\end{array}$ & & $\begin{array}{l}85 \% \\
15 \%\end{array}$ \\
\hline Induction & $\begin{array}{l}\text { Teacher Induction Program } \\
\text { (T1515) }\end{array}$ & $0=$ No; $1=$ Yes & 754,100 & $\begin{array}{l}71 \% \\
29 \%\end{array}$ \\
\hline Teacher support & $\begin{array}{l}\text { First-year support (T1516, } \\
\text { T1517, T1518, T1519, T1520, } \\
\text { T121, T1522) }\end{array}$ & $\begin{array}{l}\text { Continuous (Sum of T1516, } \\
\text { T1517, T1518, T1519, T1520, } \\
\text { T121, T1522) }\end{array}$ & & $\begin{array}{l}M=3.44 \\
S D=1.72\end{array}$ \\
\hline Mentor_freq & $\begin{array}{l}\text { Frequency working with the } \\
\text { assigned mentor teacher in the } \\
\text { first year (T1523, T1524) }\end{array}$ & $\begin{array}{l}\text { Continuous }(0=\text { none; } \\
1=\text { at least once a week, } \\
2=\text { once or twice a month; } \\
3=\text { a few times a year; } 4=\text { never })\end{array}$ & 754,100 & $\begin{array}{l}M=1.33 \\
S D=1.04 \\
M=2.25\end{array}$ \\
\hline Mentor_qual & $\begin{array}{l}\text { To what extent did the assigned } \\
\text { mentor improve teaching in the } \\
\text { first year (T1523, T1530) }\end{array}$ & $\begin{array}{l}\text { Continuous }(0=\text { none; } \\
1 \text { = not at all; } 2 \text { = to a small extent; } \\
3 \text { = to a moderate extent; } \\
4 \text { = to a great extent })\end{array}$ & & $S D=1.47$ \\
\hline MLL\% & $\begin{array}{l}\text { Percentage of teacher's students } \\
\text { who are multilingual learners }\end{array}$ & Continuous & 601,140 & $\begin{array}{l}M=11.32 \\
S D=20.65\end{array}$ \\
\hline
\end{tabular}




\begin{tabular}{|c|c|c|c|c|}
\hline Variables & $\begin{array}{l}\text { Name and representation in } \\
\text { the NTPS and CRDC }\end{array}$ & Coding & $\begin{array}{l}\text { Weighted } \\
\text { sample }\end{array}$ & Statistics \\
\hline \multicolumn{5}{|l|}{ School level } \\
\hline MLLinstr & $\begin{array}{l}\text { Availability of multilingual-learner } \\
\text { instruction (S0130) }\end{array}$ & $\begin{array}{l}0=\mathrm{No} \\
1=\mathrm{Yes}\end{array}$ & 754,100 & $\begin{array}{l}84 \% \\
16 \%\end{array}$ \\
\hline MLLconcentr ${ }^{\mathrm{b}}$ & $\begin{array}{l}\text { Multilingual-learner concentration } \\
\text { in each school }\end{array}$ & $\begin{array}{l}1=0 \% \\
2=>0 \% \text { to }<5 \% \\
3=5 \% \text { to }<20 \% \\
4=>20 \%\end{array}$ & 711,430 & $\begin{array}{l}18 \% \\
28 \% \\
43 \% \\
11 \%\end{array}$ \\
\hline SES & $\begin{array}{l}\text { Percentage of enrolled students } \\
\text { approved for the National School } \\
\text { Lunch Program (NSLAPP_S, } \\
\text { created by NCES) }\end{array}$ & Continuous & 727,260 & $\begin{array}{l}M=56.56 \\
S D=31.07\end{array}$ \\
\hline Location & $\begin{array}{l}\text { School locale (URBANS12, } \\
\text { created by NCES) }\end{array}$ & $\begin{array}{l}0=\text { Town } / \text { rural } \\
1=\text { City } / \text { suburb }\end{array}$ & 754,100 & $\begin{array}{l}34 \% \\
35 \% \\
11 \% \\
20 \%\end{array}$ \\
\hline Level & $\begin{array}{l}\text { School level (SCHLEV_4CAT, } \\
\text { created by NCES) }\end{array}$ & $\begin{array}{l}0=\text { Middle } / \text { high } / \text { combined } \\
1=\text { Elementary }\end{array}$ & 754,100 & $\begin{array}{l}52 \% \\
48 \%\end{array}$ \\
\hline Size & $\begin{array}{l}\text { Total K-12 student enrollment } \\
\text { (ENRK12UG, created by NCES) }\end{array}$ & Continuous & 754,100 & $\begin{array}{l}M=809.26 \\
S D=721.28\end{array}$ \\
\hline
\end{tabular}

Source. U.S. Department of Education, National Center for Education Statistics, National Teacher and Principle Survey (NTPS), "Public School Teacher Restricted-Use Data File" and "Public School Restricted-Use Data File," 2015 to 2016.

Note. NTPS = National Teachers and Principal Survey; CDD = Civil Rights Data Collection; $S D=$ standard deviation; NCES = National Center for Education Statistics; HIDEGR = highest degree; MLL = multilingual learner; LEP = limited-English proficient; NSLAPP = National School Lunch Program.

a. Multilingual learner.

b. Data were extracted from the Civil Rights Data Collection.

Anthony-Stevens, V., \& Langford, S. (2020). "What do you need a course like that for?" Conceptualizing diverse ruralities in rural teacher education. Journal of Teacher Education, 71(3), 332-344. https://doi.org/10.1177/0022487119861582

Babinski, L. M., Amendum, S. J., Knotek, S. E., Sánchez, M., \& Malone, P. (2018). Improving young English learners' language and literacy skills through teacher professional development: A randomized controlled trial. American Educational Research Journal, 55(1), 117-143.

Barley, Z. A., \& Wegner, S. (2010). An examination of the provision of supplemental educational services in nine rural schools. Journal of Research in Rural Education, 25(5), 1-14.

Blank, R. K., de las Alas, N., \& Smith, C. (2008). Does teacher professional development have effects on teaching and learning? Analysis of evaluation findings from programs for mathematics and science teachers in 14 states. Council of Chief State School Officers. https://ncela.ed.gov/rcd/bibliography/BE024621

Bollin, G. G. (2007). Preparing teachers for Hispanic immigrant children: A service learning approach. Journal of Latinos and Education, 6(2), 177-189. https://doi. org/10.1080/15348430701305028 
Catalano, T., Kiramba, L. K., \& Viesca, K. (2020). Transformative interviewing and the experiences of multilingual learners not labeled "ELL" in US schools. Bilingual Research Journal, 43(2), 178-195.

Catalano, T., Reeves, J. R., \& Wessels, S. (2018). “The soccer field, it has dirt”: A critical analysis of teacher learners in contact with emergent multilingual students. Critical Inquiry in Language Studies, 15(1), 1-20. https://doi.org/10.1080/15427 $\underline{587.2017 .1329626}$

Civic Impulse. (2016). S. 1177 (114th): Every student succeeds act. https://www. govtrack.us/congress/bills/114/s1177

Clark-Goff, K., \& Eslami, Z. (2016). Exploring change in preservice teachers' beliefs about English language learning and teaching. Iranian Journal of Language Teaching Research, 4(3), 21-36.

Coady, M., Harper, C., \& de Jong, E. (2011). From preservice to practice: Mainstream elementary teacher beliefs of preparation and efficacy with English language learners in the State of Florida. Bilingual Research Journal, 34(2), 223-239. https://doi.org/10.1080/15235882.2011.597823

Cohen, J. (1992). A power primer. Psychological Bulletin, 112(1), 155-159.

Daniel, S. M. (2014). Learning to educate English language learners in pre-service elementary practicums. Teacher Education Quarterly, 41(2), 5-28.

Danielson, C. (1999). Mentoring beginning teachers: The case for mentoring. Teaching and Change, 6(3), 251-257.

Darling-Hammond, L., Chung, R., \& Frelow, F. (2002). Variation in teacher preparation: How well do different pathways prepare teachers to teach? Journal of Teacher Education, 53(4), 286-302. https://doi.org/10.1177/0022487102053 $\underline{004002}$

Davis, J. E., \& Jordan, W. J. (1994). The effects of school context, structure, and experiences on African American males in middle and high school. The Journal of Negro Education, 63(4), 570-587. https://doi.org/10.2307/2967296

Diaz-Rico, L. T. (2020). A course for teaching English learners. Pearson.

Doherty, R. W., \& Hilberg, R. S. (2007). Standards for effective pedagogy, classroom organization, English proficiency, and student achievement. The Journal of Educational Research, 101(1), 24-35. https://doi.org/10.3200/JOER.101.1.24-35

Durgunoğlu, A. Y., \& Hughes, T. (2010). How prepared are the U. S. preservice teachers to teach English language learners? International Journal of Teaching \& Learning in Higher Education, 22(1), 32-41.

Faltis, C. J., \& Valdés, G. (2016). Preparing teachers for teaching in and advocating for linguistically diverse classrooms: A vade mecum for teacher educators. In D. H. Gitomer \& C. A. Bell (Eds.), Handbook of research on teaching (pp. 549-592). American Educational Research Association.

Fitts, S., \& Gross, L. A. (2012). Teacher candidates learning from English learners: Constructing concepts of language and culture in Tuesday's tutors after-school program. Teacher Education Quarterly, 39(4), 75-95.

Frankenberg, E., Ee, J., Ayscue, J. B., \& Orfield, G. (2019). Harming our common future: America's segregated schools 65 years after Brown. University of California, Los Angeles. https://escholarship.org/uc/item/23j1b9nv 
Galguera, T. (2011). Participant structures as professional learning tasks and the development of pedagogical language knowledge among preservice teachers. Teacher Education Quarterly, 38(1), 85-106.

García, O., Johnson, S. I., \& Seltzer, K. (2017). The translanguaging classroom: Leveraging student bilingualism for learning. Caslon.

Glazerman, S., Isenberg, E., Dolfin, S., Bleeker, M., Johnson, A., Grider, M., ... Easton, J. Q. (2010). Impacts of comprehensive teacher induction: Final results from a randomized controlled study (No. NCEE 2010-4027). U.S. Department of Education.

Goldrick, L., Osta, D., Barlin, D., \& Burn, J. (2012). Review of state policies on teacher induction. New Teacher Center.

Hamann, E. T., \& Reeves, J. (2013). Interrupting the professional schism that allows less successful educational practices with multilingual learners to persist. Theory Into Practice, 52(2), 81-88.

Han, K. T., \& Leonard, J. (2017). Why diversity matters in rural America: Women faculty of color challenging whiteness. The Urban Review, 49(1), 112-139. https://doi.org/10.1007/s11256-016-0384-7

Hansen-Thomas, H., Grosso Richins, L., Kakkar, K., \& Okeyo, C. (2016). I do not feel I am properly trained to help them! Rural teachers' perceptions of challenges and needs with English language learners. Professional Development in Education, 42(2), 308-324.

Hilberg, R. S., Tharp, R. G., \& DeGeest, L. (2000). The efficacy of CREDE's standardsbased instruction in American Indian mathematics classes. Equity \& Excellence in Education, 33(2), 32-40. https://doi.org/10.1080/1066568000330206

Hox, J. J., Moerbeek, M., \& Van de Schoot, R. (2017). Multilevel analysis: Techniques and applications (3rd ed.). Routledge.

Huseby, S. (2018). Effective characteristics of rural English learner programs. Minnesota State University Press.

Ingersoll, R. M., \& Strong, M. (2011). The impact of induction and mentoring programs for beginning teachers: A critical review of the research. Review of Educational Research, 81(2), 201- 233. https://doi. org/10.3102/0034654311403323

Jimenez-Silva, M., \& Olson, K. (2012). A community of practice in teacher education: Insights and perceptions. International Journal of Teaching and Learning in Higher Education, 24(3), 335-348.

Kaufmann, J. (2007). Induction programs for new and beginning teachers. Education Commission of the States.

López, F., \& McEneaney, E. (2012). State implementation of language acquisition policies and reading achievement among Hispanic students. Educational Policy, 26(3), 418-464. https://doi.org/10.1177/0895904811417581

Lucas, T., Villegas, A. M., \& Freedson-Gonzalez, M. (2008). Linguistically responsive teacher education: Preparing classroom teachers to teach English language learners. Journal of Teacher Education, 59(4), 361-373. https://doi. org/10.1177/0022487108322110 
Ma, X., Ma, L., \& Bradley, K. D. (2008). Using multilevel modeling to investigate school effects. In A. A. O'Connell \& D. B. McCoach (Eds.), Multilevel modeling of educational data (pp. 59-110). Information Age.

Martin-Beltran, M., \& Peercy, M. M. (2014). Collaboration to teach English language learners: Opportunities for shared teacher learning. Teachers and Teaching, 20(6), 721-737. https://doi.org/10.1080/13540602.2014.885704

Master, B., Loeb, S., Whitney, C., \& Wyckoff, J. (2016). Different skills? Identifying differentially effective teachers of English language learners. The Elementary School Journal, 117(2), 261-284. https://doi.org/10.1086/688871

McFarland, J., Hussar, B., Zhang, J., Wang, X., Wang, K., Hein, S., . . Purcell, S. (2019). The condition of education 2019 (No. NCES 2019-144). National Center for Education Statistics. https://nces.ed.gov/pubsearch/pubsinfo. asp?pubid $=2019144$

Mitchell, K., Homza, A., \& Ngo, S. (2012). Reading aloud with bilingual learners: A fieldwork project and its impact on mainstream teacher candidates. Action in Teacher Education, 34(3), 276-294. https://doi.org/10.1080/01626620.2012.69 $\underline{4020}$

Nieto, S. (2000). Placing equity front and center: Some thoughts on transforming teacher education for a new century. Journal of Teacher Education, 51(3), 180 187. https://doi.org/10.1177/0022487100051003004

O'Neal, D. D., Ringler, M., \& Rodriguez, D. (2008). Teachers' perceptions of their preparation for teaching linguistically and culturally diverse learners in Rural Eastern North Carolina. The Rural Educator, 30(1), 5-13. https://doi. org/10.35608/ruraled.v30i1.456

Peercy, M. M., Martin-Beltrán, M., Silverman, R. D., \& Nunn, S. J. (2015). “Can I ask a question?" ESOL and mainstream teachers engaging in distributed and distributive learning to support English language learners' text comprehension. Teacher Education Quarterly, 42(4), 33-58.

Perie, M., \& Baker, D. P. (1997). Job satisfaction among America's Teachers: Effects of workplace conditions, background characteristics, and teacher compensation, Numerical/Quantitative Data, 110) Reports No. NCES-97-471). American Institutes for Research.

Peugh, J. L. (2010). A practical guide to multilevel modeling. Journal of School Psychology, 48(1), 85-112. https://doi.org/10.1016/j.jsp.2009.09.002

Polat, N. (2010). A comparative analysis of pre-and in-service teacher beliefs about readiness and self-competency: Revisiting teacher education for ELLs. System, 38(2), 228-244. https://doi.org/10.1016/j.system.2010.03.004

Reeves, J. R. (2006). Secondary teacher attitudes toward including English-language learners in mainstream classrooms. The Journal of Educational Research, 99(3), 131-143. https://doi.org/10.3200/JOER.99.3.131-143

Rodriguez, D., Manner, J., \& Darcy, S. (2010). Evolution of teacher perceptions regarding effective instruction for English language learners. Journal of Hispanic Higher Education, 9(2), 130-144. https://doi.org/10.1177/1538192709359423 
Ronfeldt, M., \& McQueen, K. (2017). Does new teacher induction really improve retention? Journal of Teacher Education, 68(4), 394-410. https://doi. org/10.1177/0022487117702583

Schall-Leckrone, L., \& McQuillan, P. J. (2012). Preparing history teachers to work with English learners through a focus on the academic language of historical analysis. Journal of English for Academic Purposes, 11(3), 246-266. https://doi. org/10.1016/j.jeap.2012.05.001

Shaw, J., Lyon, E., Stoddart, T., Mosqueda, E., \& Menon, P. (2014). Improving science and literacy learning for English language learners: Evidence from a pre-service teacher preparation intervention. Journal of Science Teacher Education, 25(5), 621-643.

Shen, J., Leslie, J. M., Spybrook, J. K., \& Ma, X. (2012). Are principal background and school processes related to teacher job satisfaction? A multilevel study using Schools and Staffing Survey 2003-04. American Educational Research Journal, 49(2), 200-230. https://doi.org/10.3102/0002831211419949

Showalter, D., Klein, R., Johnson, J., \& Hartman, S. L. (2017). Why rural matters 20152016: Understanding the changing landscape. The Rural School and Community Trust.

Skaalvik, E. M., \& Skaalvik, S. (2009). Does school context matter? Relations with teacher burnout and job satisfaction. Teaching and Teacher Education, 25(3), 518524. https://doi.org/10.1016/j.tate.2008.12.006

Smith, T. M., \& Ingersoll, R. M. (2004). What are the effects of induction and mentoring on beginning teacher turnover? American Educational Research Journal, 41(3), 681-784.

Sowa, P. A. (2009). Understanding our learners and developing reflective practice: Conducting action research with English language learners. Teaching and Teacher Education, 25(8), 1026-1032. https://doi.org/10.1016/j.tate.2009.04.008

Sullivan, B., Hegde, A. V., Ballard, S. M., \& Ticknor, A. S. (2015). Interactions and relationships between kindergarten teachers and English language learners. Early Child Development and Care, 185(3), 341-359. https://doi.org/10.1080/0300443 $\underline{0.2014 .919496}$

Swanson, L. H., Bianchini, J. A., \& Lee, J. S. (2014). Engaging in argument and communicating information: A case study of English language learners and their science teacher in an urban high school. Journal of Research in Science Teaching, 51(1), 31-64. https://doi.org/10.1002/tea.21124

Tandon, M., Viesca, K. M., Hueston, C., \& Milbourn, T. (2017). Perceptions of linguistically responsive teaching in teacher candidates/novice teachers. Bilingual Research Journal, 40(2), 154-168. https://doi.org/10.1080/15235882.2017.130 $\underline{4464}$

Teemant, A., \& Hausman, C. S. (2013). The relationship of teacher use of critical sociocultural practices with student achievement. Critical Education, 4(4), 1-20.

Turgut, R., Sahin, E. A., \& Huerta, M. (2016). Changes in preservice teachers' perceptions of preparedness to teach English language learners (ELLs) in mainstream classrooms. Journal of Ethnographic \& Qualitative Research, 10(4), 291-305. 
U.S. Department of Education (2017). Our nation's English learners. What are their characteristics? https://www2.ed.gov/datastory/el-characteristics/index. html\#intro

Valdés, G. (2001). Learning and not learning English: Latino students in American schools. Teachers College Press.

Vaughn, M., \& Saul, M. (2013). Navigating the rural terrain: Educators' visions to promote change. The Rural Educator, 34(2), 1-9.

Viesca, K. M., \& Teemant, A. (2019). Preparing mainstream content teachers to work with bi/multilingual students. In L. C. de Oliveira (Ed.), The Handbook of TESOL in K-12 (pp. 371-386). Wiley.

Vygotsky, L. S. (1980). Mind in society: The development of higher psychological processes. Harvard University Press.

Walker, D., Mahon, E., \& Dray, B. (2017). Can we prepare culturally and linguistically responsive teachers online? A cross-case analysis of online and on-campus courses. Urban Education. Advance online publication. https://doi. org/10.1177/0042085917735970

Wang, M.-T., \& Eccles, J. S. (2013). School context, achievement motivation, and academic engagement: A longitudinal study of school engagement using a multidimensional perspective. Learning and Instruction, 28, 12-23. https://doi. org/10.1016/j.learninstruc.2013.04.002

Wenger, K. J., Dinsmore, J., \& Villagómez, A. (2012). Teacher identity in a multicultural rural school: Lessons learned at Vista Charter. Journal of Research in Rural Education, 27(5), 1-17.

\section{The Authors}

Qizhen Deng is an assistant professor of Literacy, Language and Culture at Boise State University. Her scholarly interest focuses on the cognitive and motivational processes of language development for multilingual learners as well as teacher education for teachers who works with diverse populations.

Lydiah Kananu Kiramba is an assistant professor of educational linguistics at the University of Nebraska-Lincoln. Her research examines communicative practices of multilingual students in super-diverse classrooms, and literacies of migrants, immigrants, and multilingual populations in K-12 classrooms.

Kara Mitchell Viesca, PhD, is an Associate Professor of Teaching, Learning and Teacher Education at the University of Nebraska-Lincoln. Her scholarship focuses on advancing equity in the policy and practice of teacher development, particularly for teachers of multilingual learners. 